\title{
A stroma szerepe a tumorok kialakulásában és progressziójában
}

\author{
Baranyi Marcell - Lippai Mónika dr. - Szatmári Zsuzsanna dr. \\ Eötvös Loránd Tudományegyetem, Anatómiai, Sejt- és Fejlődésbiológiai Tanszék, Budapest
}

\begin{abstract}
Az elmúlt évtizedben egyre nagyobb figyelem helyeződött arra, hogy rákos megbetegedések során a tumorok nem csupán a kórosan osztódó, mutációkat hordozó sejtekből állnak, hanem valójában komplex „szövetnek” tekinthetők. Ugyanis a folyamatban elengedhetetlenül fontos szerepet játszanak a tumorsejteket körülvevő egyéb szöveti sejtek is, hiszen segítő mikrokörnyezet nélkül a tumor nem lenne képes kialakulni és fejlődni. A következő rövid összefoglaló bemutatja, hogyan befolyásolják a stromasejtek a tumor kialakulását, fejlődését, milyen szerepet játszik a gyulladás a tumor progressziójában, miként segíthetik a hypoxiás állapotok feloldására formálódó új erezet kialakulását a tumorban jellemzően jelen lévő egészséges testi sejtek. Bemutatásra kerülnek azok a főbb mechanizmusok is, amelyek során a stromasejtek segítségével a rákos sejtek elkerülik az immunrendszer tumorpusztító hatásait. A stroma rendkívül komplexen hozzájárul a daganatos sejtek invazív magatartásához, intravasatiójához és az áttétképzéshez. Végezetül szó esik néhány lehetséges terápiás lehetőségről, amelyek a stromát, annak tumorsegítő mechanizmusait célozva hatékony megoldást jelenthetnek a rákos megbetegedésekkel szemben. Orv. Hetil., 2015, 156(45), 1816-1823.
\end{abstract}

Kulcsszavak: daganat, mikrokörnyezet, stroma

\section{Role of the stroma in the initiation and progression of tumors}

In the last decade, growing attention was paid to the observation that tumors did not only consist of cancer cells, they are rather a complex tissue-like mixture of tumor and stromal cells, which are playing an important role in the course of the malignant disease. Their contribution is so essential that without them, tumors are not even able to grow. This short review summarizes how stromal cells can help the cancerous transformation and early development of tumors, how chronic inflammation contributes to the progression of cancer and how stroma takes part in the induction of angiogenesis. The main mechanisms by which tumors can escape the immune surveillance will be demonstrated as well as the complex contributions of stroma to the invasion, intravasation and metastasis of cancer cells. Finally, possible and promising therapies will be presented that aim at the stroma and its main effects on the progression of tumors.

Keywords: cancer cell, microenvironment, stroma

Baranyi, M., Lippai, M., Szatmári, Zs. [Role of the stroma in the initiation and progression of tumors]. Orv. Hetil., $2015,156(45), 1816-1823$.

(Beérkezett: 2015. szeptember 9.; elfogadva: 2015. szeptember 24.)

\section{Rövidítések}

$\mathrm{ECM}=$ extracelluláris mátrix; $\mathrm{EGF}=$ epithelial growth factor; $\mathrm{FAK}=$ focal adhesion kinase; $\mathrm{IDO}=$ indolamin-2,3-dioxigenáz; IFN = interferon; IL = interleukin; iNOS = indukálható nitrit-oxid-szintáz; MDSC = myeloid-derived suppressor cell; $\mathrm{MMP}=$ matrix metalloproteinase; NF- $\kappa \mathrm{B}=$ nukleáris faktorkappa B; NK-sejt $=($ natural killer cell $)$ természetes ölősejt;
PDGF = platelet derived growth factor; PlGF = placental growth factor; SDF-1 = stromal derived factor- 1 ; Tc-sejtek = citotoxikus T-sejtek; TCR $=$ T-sejt-receptor; TGF- $\beta=($ transforming growth factor- $\beta$ ) transzformáló növekedési faktor- $\beta$; TNF- $\alpha=$ tumornekrózis-faktor- $\alpha$; Treg-sejtek $=$ regulár T-sejtek; VEGF = vascular endothelial growth factor; VEGFRI = VEGF-receptor-1 


\section{A stroma szerepe a tumor iniciációjában}

Tumorstroma alatt a tumor kötőszöveti környezetét, az itt természetesen is megtalálható, állandó sejteket (fibroblastok, adipocyták, endothelsejtek, pericyták), illetve a gyulladási folyamatok és kemoattraktív faktorok hatására a helyszínre vándorolt immunrendszeri sejteket értjük.

A daganatos megbetegedések kialakulása a szervezetben soklépcsős folyamat, a kiindulást jelentő rákos sejtnek több, különböző mutációs eseményt kell elszenvednie, hogy korlátlan proliferációja bekövetkezhessen. A spontán bekövetkező mutációk mellett számos hatás iniciátorként múködhet, ilyen lehet például az UV-sugárzás vagy a különböző kémiai mutagének. Egyes elképzelések szerint a stroma sejtjei is betölthetik ezt a funkciót, például a gyulladási folyamatok során a makrofágok és egyéb immunsejtek által termelt reaktívoxigén-gyökök hatásán keresztül. Ezt az elméletet támasztja alá az az általános tapasztalat is, hogy a krónikus gyulladások, többek között a vastagbélben, jelentősen megnövelik a daganatok kialakulásának kockázatát [1].

\section{A tumor mikrokörnyezetének átalakulása}

A rákos sejtek kialakulásuk után képesek különböző egészséges szöveti sejteket maguk köré toborozni, és múködésüket megváltoztatni: olyan folyamatokat indukálnak bennük, amelyekkel azok a tumorsejtek túlélését, osztódását és a daganat progresszióját segítik. A reaktív, tumorsegítő mikrokörnyezet legfontosabb jellemzői az aktivált fibroblastok jelenléte, az egészségestől eltérő összetételú és mennyiségú extracelluláris mátrix (ECM), illetve a gyulladásos környezet.

A stromasejtek toborzása különböző parakrin jelzőmolekulák segítségével történhet. A fibroblastoké többek között vérlemezke-eredetű növekedési faktorral (platelet derived growth factor - PDGF) és transzformáló növekedési faktor $\beta$-val (transforming growth factor- $\beta$ - TGF- $\beta$ ) [2, 3]. A fibroblastok aktiválásával a tumoraszszociált stroma egyik legfontosabb komponense jön létre. Az aktivált fibroblastok megváltozott génexpressziós mintázatot mutatnak, ennek következménye az egészséges körülmények között megfigyelhetőtől eltérő, fibroticus jellegü ECM a tumor-mikrokörnyezetben. Ez különböző típusú emlőrákok esetében jóval merevebb, tömörebb sejt közötti állományt eredményez [4]. Az erezet összenyomódásával csökken a perfúzió, valamint a különböző citotoxikus szerek számára kevésbé átjárható mikrokörnyezet jön létre, ami gyengítheti a kemoterápia hatékonyságát [5].

Gyakori jelenség, hogy a sejt-sejt kapcsolatokban szerepet játszó E-kadherin-molekula kifejeződése csökken vagy gátlódik a rákos sejteken. Az E-kadherin elsősorban az epithelsejtek közötti kapcsolatok kialakításában jelentôs transzmembránfehérje, antiproliferatív és migrációt gátló hatásának köszönhetően fontos szereplő a hámszö- vet homeosztázisának és integritásának fenntartásában. A megváltozott ECM, például a hasnyálmirigytumorokban, gyakran túlexpresszálódó I-es típusú kollagén [6], amely képes a szomszédos hámsejtek között kialakult Ekadherin-komplexek szétválását okozni. Ennek következtében az E-kadherin citoszolikus részéhez kötődő $\beta$-katenin transzkripciós faktor leválik, a sejtmagba transzlokálódik, ahol különböző, proliferációt serkentő gének átírását aktiválja [7].

Az ECM bizonyos bioaktív anyagoknak - például növekedési faktorok, angiogenezist szabályozó molekulák - fontos raktára. Amennyiben ezek felszabadulnak és hozzáférhetővé válnak a daganatos sejtek számára, hozzájárulhatnak a proliferatív jelátvitel fenntartását biztosító külső hatásokhoz [4]. Tumorokban a mátrixbontó enzimek gyakran abnormális mértékben fejeződnek ki, elsősorban aktivált fibroblastok, tumorasszociált makrofágok, illetve sokszor maguk a rákos sejtek termelik őket. A mátrixmetalloproteinázok (matrix metalloproteinase - MMP), fajtájuktól függően, többféle hatást is ki tudnak fejteni, rendkívül fontos szereplők a tumor progreszsziójában. Az MMP-9 például a TGF- $\beta$ kötött formáját hasítva aktív faktorrá képes azt alakítani, amivel hozzájárul az immunszuppresszív miliő kialakulásához [8]. Az ADAM-10 az E-kadherint hasítja, ami a $\beta$-katenin sejtmagba történő transzlokációját eredményezi és a rákos sejtek proliferációját serkentheti [9].

\section{A gyulladásos folyamatok szerepe a tumor fejlődésében}

Rákos megbetegedésekre gyakran utalnak úgy a szakirodalomban, mint „nem gyógyuló sebekre”. Ennek egyik oka a daganatokra már korai stádiumoktól fogva jellemző gyulladásos környezet. A daganat kialakulását gyakran eleve gyulladás iniciálja, például makrofágok által termelt reaktívoxigén-gyökök felszabadulása révén, más esetekben a tumor progressziójának kezdeti lépéseiben alakul ki a gyulladásos környezet. A reaktívoxigén- és -nitrogén-gyökök intenzív termelése a rákos sejtek mutációs rátájának növekedését serkentheti, aminek következtében a tumorsejtek „mikroevolúciója” felgyorsulhat.

A különböző, maga a tumor vagy a tumorasszociált stroma által termelt kemokinek, gyulladási mediátorok hatására a tumor mikrokörnyezetében jelentős mennyiségú immunrendszeri sejt jelenik meg. A krónikus gyulladáshoz hasonlóan azonban itt is kiemelt szerepet kap az immunológiai tolerancia, ami fertőzések esetén az elhúzódó gyulladási folyamatok helyi, illetve szisztémás sejt- és szövetkárosító hatásait hivatott szabályozni. A daganatos sejtek kemokinek, például a CCL21 termelésével képesek kemotaktikus hatást gyakorolni az immunológiai toleranciát biztosító regulátor T-sejtekre (Tregsejtek), valamint a myeloid eredetû szuppresszor sejtekre (myeloid-derived suppressor cells - MDSC) [10]. Ezek gátolják az immunrendszer effektor, tumorellenes hatást kifejtő citotoxikus T-sejtjeit (Tc-sejtek) és a természetes 
ölősejteket (natural killer cells - NK-sejtek), így biztosítják a rákos sejtek túlélését $[11,12]$.

A gyulladásos folyamatok során megjelenő, úgynevezett tumorasszociált makrofágok sokféleképpen tudják befolyásolni a tumor progresszióját. Ez nagyfokú plasztikusságukból ered, ugyanis megfelelő citokinek kibocsátásával a tumorsejtek eltérő fenotípusokat tudnak belőlük kiváltani. A makrofágokra ható faktoroktól függően két ellentétes aktivitású makrofágtípus jöhet létre, a „klasszikusan” aktivált Ml típus, amely antitumor-aktivitást fejt ki és jelenléte jobb prognózist eredményez a rákos betegeknél, illetve az M2 típus, amely többek között gyulladási mediátorok, növekedési faktorok, angiogenezist indukáló anyagok termelésével és immunregulátor funkciójú sejtek toborzása révén éppen a tumor túléléséhez és fejlődéséhez járul hozzá [13].

\section{Hypoxia és angiogenezis}

A tumor növekedése során kialakult hypoxia megszüntetésére a legtöbb tumorban új erezet formálódik, hasonlóan más patológiás állapotok, például sérülések következtében kialakult alacsony oxigénkoncentrációjú állapotokhoz. Az új erezet kialakulásának indukciója fóként a vascularis endothelialis növekedési faktorhoz (vascular endothelial growth factor - VEGF) köthető, azonban a stroma különböző sejtjei, például az aktivált fibroblastok csoportja, bizonyos esetekben - többek között PDGF-C termelésével - biztosíthatják a rezisztenciát egyes, a VEGF neutralizációját célzó terápiákkal szemben [14]. Bizonyos tumorokban pedig stromaeredetü faktor-1-et (stromal derived factor-1 - SDF-1) szekretálva endothel progenitor sejtekre fejtenek ki kemotaktikus hatást, ami szintén segíti az új erezet formálódását [15].

$\mathrm{Az}$ immunrendszer sejtjei szintén jelentős mértékben járulnak hozzá az új erezet kialakulásához. A tumoraszszociált makrofágok a VEGF-A és egyéb, angiogenezist indukáló faktorok egyik legfontosabb forrásának számítanak. Egyes tumorokban a jelen lévő makrofágok VEGF-A génjének deletiója az erezet sűrüségének csökkenéséhez, majd normalizálódásához vezetett [16]. A makrofágok a tumorasszociált fibroblastokhoz hasonlóan alternatív úton, placentaeredetú növekedési faktor (placental growth factor - PlGF) termelésen keresztül is indukálhatják az angiogenezist, ami megint csak lehetőséget biztosít az anti-VEGF-terápiára rezisztens tumorok kialakulására [17].

\section{Az „immunoediting” folyamata és a gyulladás szerepe a rák progressziójában}

A kezdeti elképzelések szerint az immunrendszernek a rákos sejtek megjelenésére adott válasza egy „mindent vagy semmit" típusú kölcsönhatás - ennek megfelelően tehát a daganatok létrejötte az immunválasz egyértelmú vereségét jelentené. Újabb tanulmányok alapján vezették be az „immunoediting” fogalmát az immunrendszer és a tumorok kölcsönhatásainak pontosabb leírására, amely kölcsönös alakításra, befolyásolásra utal. Eszerint az immunválasz egyfajta szelekciós erőként múködhet: újabb, az immunrendszer hatásaival szemben rezisztensebb, ellenállóbb rákos sejtek előtérbe kerülését támogathatja, ezáltal képes nagyban befolyásolni a tumoros megbetegedések progresszióját. Ugyanakkor - például különböző szekretált faktorok segítségével - a tumor is folyamatosan alakíthatja az immunválaszt, ennek következménye többek között a tumorsegítő, krónikus gyulladás a daganat területén.

Az immunrendszer és a tumor közös fejlődése közben jellemző kölcsönhatásokat három fó stádiumra, az eliminációra, az egyensúlyra és az elkerülésre különítik el (ezekre gyakran „a három E”-ként is utalnak).

Az elimináció stádiuma megfelel az immunrendszer szerepéról alkotott korábbi elképzeléseknek: a veleszületett és adaptív immunrendszeri effektor sejtek specifikusan felismerik a rákos sejteket, és különböző mechanizmusok segítségével elpusztítják azokat. Ez egyúttal szelekciós nyomást is jelent a tumor számára: az alacsonyabb immunogenitású változatok maradnak életben. Amennyiben sikerül az elimináció fázisában az összes tumoros sejtet elpusztítani, az „immunoediting” végpontját ez a szakasz jelenti.

Az „immunoediting” során általában az egyensúlyi stádiumot tekintik a leghosszabbnak - akár évekig, évtizedekig is elhúzódhat. Ekkor ugyanis egyensúlyi állapot jön létre a szervezet védekező válasza és a tumor progressziója között: az immunrendszer bizonyos mértékben féken tudja tartani a tumor növekedését, megakadályozza annak túlnövését, makroszkopikus daganattá alakulását.

Amennyiben a rákos sejtek képesek olyan mechanizmus(oka)t kialakítani, amely(ek) segítségével az immunrendszer védekezőmechanizmusait sikerül elkerülniük, a tumor progressziója tovább folytatódhat és gyors növekedés indulhat be. A tumorok az elkerülést alapvetően három fő, egymást nem kizáró módon képesek megvalósítani: 1. csökkent hatásfokkal képesek óket felismerni az immunrendszer effektor sejtjei; 2. rezisztenciát kialakító, illetve túlélést indukáló faktorok termelésére válnak képessé; 3. immunszuppresszív mikrokörnyezetet alakítanak ki [18].

A stromasejtek hozzájárulása a tumor progressziójához elsősorban a legtöbb tumorra jellemzố immunszuppresszív miliő kialakulásához kapcsolódik.

\section{Immunszuppresszív szolúbilis faktorok és enzimek a tumor-mikrokörnyezetben}

Az immunszuppresszív környezet létrejöttét a stroma leggyakrabban különböző szolúbilis állapotú szekretált faktorok révén segíti elő. Ezek egyrészt regulátor immunrendszeri sejteket toboroznak a tumor környezeté- 
be, másrészt direkt hatást is kifejthetnek: gátolhatják különböző effektor sejtek aktivitását [18].

Az előbbi csoportba tartozik a tumorsejtek mellett egyes stromasejtek, például a makrofágok által is szekretált VEGF, amely az angiogenezisben betöltött szerepe mellett az éretlen myeloid eredetú sejtekre is kemoattraktáns hatást gyakorol, ezáltal biztosítva a tumorasszociált makrofágok és az éretlen dendritikus sejtek utánpótlását [19]. A VEGF ugyanakkor úgy is hozzájárulhat a tumor fejlődéséhez, hogy az NF- $\kappa$ B transzkripciós faktor aktiválódásának gátlásával akadályozza a dendritikus sejtek differenciálódását és érését [20]. Hasonló hatása van a tumor területén általában magas koncentrációt mutató TGF- $\beta$-nak is: fontos szerepe van a regulátor immunsejtek indukálásában, az effektor sejtek aktivitásának gátlásában, illetve tumorsegítő fenotípusuk kialakításában [21]. A szuppresszív környezet kialakítása során a tumor által toborzott különböző stromasejtek termelte interleukin-10 (IL-10) is nagyon fontos citokin. Többek között gátolja az antigén-prezentálás folyamatát és az IL-12-termelést [22], ezenkívül akadályozza a dendritikus sejtek érését és differenciálódását is [23].

Az immunszuppresszióhoz a tumor-mikrokörnyezetben található T-sejtek aktivitásának gátlása is hozzájárul, amelyet gyakran két aminosav, a triptofán és az arginin megvonása vált ki. Ebben két fontos enzim, az indolamin-2,3-dioxigenáz (IDO), illetve az argináz játszik szerepet: mindkét enzim termelésében részt vesznek a tumor által toborzott regulátor immunsejtek, makrofágok, MDSC-k [24, 25].

Az IDO termelése az egyik legfontosabb immunregulátor mechanizmus a szervezetben. A rákos megbetegedések során is nagy jelentősége van, mivel az IDO a legtöbb tumorban túltermelődik [26]. Ez az enzim a triptofán lebontását, illetve kinureninné történő alakítását katalizálja; aktivitása nyomán triptofánéhezés alakulhat ki a T-sejtekben, amelyek ennek következtében nem képesek osztódni és aktiválódni [27].

Hasonló eredményekkel jár a másik immunszuppreszszív hatású enzim, az argináz aktivitása is. Az argináz expressziója az L-arginin-metabolizmusban szintén szerepet játszó indukálható nitrit-oxid-szintáz (iNOS) enzimmel reciprok kapcsolatban van. Amíg az iNOS-t alapvetően Thl típusú citokinek serkentik (IFN- $\gamma$ ), amelyek az argináztermelést gátolják, addig a Th2 típusú citokinek (IL-4, IL-10, IL-13) az arginázt serkentik és az iNOS-t gátolják [28]. Az iNOS a makrofágok és egyéb effektor sejtek citotoxikus aktivitásával hozható összefüggésbe, így az L-arginin elvonása ettől az enzimtől további hozzájárulás lehet az immunszuppresszióhoz. Az argináz másik fontos funkciója, hogy az L-arginin-éhezés kialakulásával T-sejtekben a T-sejt-receptor (T-cell receptor - TCR) ל láncának kifejeződése redukálódik, így az általa közvetített jelátviteli útvonal gátlás alá kerül, ami egyúttal az effektor T-sejtek citotoxikus aktivitását is megszünteti [29]. Ezenkívül L-arginin-éhezés hatására a ciklin-D3 és ciklindependens kináz-4 csökkent mennyi- sége figyelhető meg, és a T-sejtek osztódása a G0-Gl fázisban megáll [30].

\section{Regulátor immunrendszeri sejtek a tumor-mikrokörnyezetben}

A tumorstromában található nagy mennyiségú regulátor sejt közé elsősorban a Treg-sejtek, az éretlen, illetve a regulátor dendritikus sejtek és a myeloid eredetú szuppresszor sejtek tartoznak. Ezek a sejttípusok egymásra és effektor immunsejtekre hatva segítik a tumorfejlődés számára kedvező környezet kialakulását.

A Treg-sejteket gátló citokinek termelése és az effektor T-sejtek gátlása mellett hozzájárulnak a dendritikus sejtek éretlen vagy regulátor funkciójú állapotba juttatásához is [31].

A tumorinfiltráló dendritikus sejtek inhibitor típusú B7 kostimulátor molekula kifejezésével szintén a citotoxikus T-sejtek effektor múködését gátolhatják [32], ezenkívül stimulálhatják a Treg-sejteket is, tovább segítve az ezek által biztosított immuntolerancia kialakulását [33].

Az MDSC-k argináz- és iNOS-termelésén keresztül hozzájárulhatnak a T-sejtek L-arginin-éhezéséhez: az iNOS által generált NO indukálhatja a T-sejtek apoptózisát. Ezenkívül a NO-ból peroxinitrit keletkezhet, ami a Tc-sejtek TCR és CD8 molekuláit nitrálással inaktiválja. Az argináz és iNOS gátlásával a T-sejtek aktivitása helyreállítható [34]. A myeloid eredetű szuppresszor sejtek hatására a Treg-sejtek differenciálódása is serken [35].

\section{A premetasztatikus niche}

Bár az utóbbi időben számos előrelépés történt annak meghatározásában, hogy a tumor progressziója során melyik ráktípus esetén milyen szervek szolgálnak az áttét helyszínéül, a legtöbb esetben a „választás” hátterében álló mechanizmusok még felderítetlenek. Újabb elképzelések szerint a stromának fontos szerepe lehet az úgynevezett premetasztatikus niche létrehozásában. Az utóbbi években fény derült arra, hogy az elsődleges tumor különböző stromasejtek segítségével képes előkészíteni az áttét kialakulását távoli szervekben, szövetekben is. Ezeket a metasztatikus rákos sejteket befogadó helyszíneket hívjuk premetasztatikus niche-nek. A tumor, illetve a tumorasszociált stroma sejtjei által termelt szolúbilis faktorok, például a VEGF vagy a TNF- $\alpha$ (tumornekrózis-faktor- $\alpha-\mathrm{TNF}-\alpha$ ), kemoattraktív hatására ezeken a helyszíneken különböző éretlen csontvelői eredetű sejtek jelennek meg [36, 37], amelyek ezután kialakítják az áttéthez megfelelő környezetet. Megfigyelték azt is, hogy az elsődleges tumor által termelt liziloxidáz aktivitása nyomán keresztkötött ECM-proteinek MDSC-ket toboroznak a premetasztatikus helyszínekre. Ezek a sejtek a keresztkötött IV. típusú kollagénhez kötődnek, majd mátrixbontó enzimeket termelnek, előse- 
gítve a metasztatikus sejtek invázióját [38]. Ahogy korábban már volt róla szó, az MDSC-k ráadásul hozzájárulhatnak az immunszuppresszív miliő kialakulásához is [39].

A premetasztatikus niche-be toborzott csontvelői eredetú sejtek MMP-9-et termelnek, amelynek aktivitása hozzájárulhat a mátrixban kötött latens VEGF felszabadításához [37]. Egyes elképzelések szerint az ilyen módon mobilizált VEGF - az elsődleges tumor és stromája által szekretált VEGF-fel együtt - az áttét helyszínén az erezet permeabilitásának növelésével segítheti a tumorsejtek extravasatióját, valamint a kolonizáció utáni gyors angiogenezist is [40]. Más eredmények alapján is úgy tünik, hogy a VEGF-receptor (VEGFRl) indukálta szignalizáció fontos szerepet játszik a premetasztatikus niche kialakításában, mivel a VEGFRl-pozitív csontvelói eredetü sejtek már jóval a tumorsejtek érkezése előtt megjelennek a premetasztatikus niche-ben [37].

\section{Út az intravasatióhoz}

A tumor progressziójában fontos lépést jelent a tumorsejtek intravasatiója. A rákos sejteknek két fó problémát kell ehhez megoldaniuk: képessé kell válniuk az aktív mozgásra, illetve meg kell találniuk az erezetet. A sejtmotilitás növelésére hámeredetü tumorok esetében a legelterjedtebb mechanizmus az epithelialis-mesenchymalis átalakulás teljes vagy részleges aktiválása [41]. Ezt a folyamatot a stroma sejtjei többféleképpen is tudják iniciálni.

A tumorokban gyakran túltermelődnek a mátrixbontó enzimek; ilyen az MMP-3 is, amely a már említett E-kadherin hasításával, azaz a hámra jellemző sejt-sejt kapcsolatok felbomlásával hozzájárulhat az epithelialismesenchymalis átalakuláshoz, végeredményben a metasztázis kialakulásához [42].

Számos stromasejt, például tumorasszociált fibroblastok, TGF- $\beta$-termeléssel serkenthetik a tumorsejtek invazív, migrációs viselkedését [43].

Egy másik szolúbilis faktor, az epithelialis növekedési faktor (epithelial growth factor - EGF) pedig kemoattraktánsként irányíthatja is a migráló rákos sejtek útvonalát: megfigyelték, hogy a tumorasszociált makrofágok egy, a rákos sejtekkel együtt vándorló szubpopulációja EGF-szekrécióval segítette a tumorsejtek tumorerezethez találását [44].

\section{Invázió és metasztázisképzés: túlélés, megtelepedés}

A tumorsejtek az intravasatio után a keringésbe jutva különböző fizikai megterheléseknek vannak kitéve a véráramlás során fellépő nyíróerők miatt. Ennek kivédésére a tumorsejtek gyakran vérlemezkéket toboroznak maguk köré, és velük fizikai kapcsolatba lépve aggregátumokat alkotnak. Ez a „burok” nemcsak fizikai, hanem biológiai védelmet is biztosít a számukra, mert „elrejti” őket az immunrendszeri sejtek felismerő mechanizmusai elől is [45].

Azt, hogy a tumorsejtek odataláljanak a számukra előkészített premetasztatikus helyszínekre, a már korábban odaérkezett csontvelői eredetű sejtek, MDSC-k, aktivált fibroblastok által termelt kemoattraktánsok (például SDF-1) segítik. A különböző, premetasztatikus helyszín kialakításában és formálásában szerepet játszó éretlen csontvelői eredetű sejtek integrinek segítségével kötődnek az ECM fibronektinmolekuláihoz, ami segíti felhalmozódásukat. Az aktivált stromasejtek, például fibroblastok által szekretált nagy mennyiségü fibronektin tehát indukálja és segíti a premetasztatikus helyszínek kialakítását [37]. Bár a metasztatikus helyszínen történő megtapadás és növekedés molekuláris mechanizmusai nagyrészt feltáratlanok, vannak már ígéretes eredmények. Egy kísérletben azt találták, hogy az elsődleges tumor által termelt verzikánnal aktivált makrofágok TNF- $\alpha$-t szekretálnak, amely serkenti a tumorsejtek kolonizációját [46]. Egy másik esetben a premetasztatikus niche-ben található tüdőendothelsejtekben - az elsődleges tumorból származó VEGF hatására - a fokális adhéziós kináz (focal adhesion kinase - FAK) szintje megnövekedett és indukálta a tumorsejtek megtelepedését segítő E-kadherin expresszióját, azaz a stabil sejt-sejt kapcsolatok kialakulását [47].

Bár a sikeres megtapadás és túlélés után a metasztatikus sejteknek hasonló akadályokat kell leküzdenie, mint előtte az elsődleges tumornak, a különböző toborzott stromasejteknek köszönhetően már egy előkészített, nem ellenséges környezetben kezdhetik meg a növekedést, nagyban hozzájárulva a metasztázisképzés sikerességéhez.

\section{Következtetések}

A tumor mikrokörnyezetében található stroma sejtes és nem sejtes elemei aktív résztvevők a daganatos megbetegedések kialakulásában és progressziójában (1. ábra). Sokféle módon járulhatnak hozzá ehhez a folyamathoz: megoldásokat kínálnak a tumorsejtek előtt álló számtalan akadály leküzdésére, ezenkívül sok esetben a kemoterápiával, citotoxikus kezeléssel szembeni rezisztencia is a mikrokörnyezetben található, egyébként normális szöveti sejteknek köszönhető. A fentiek alapján joggal tekinthetünk a tumorasszociált stromára kiemelten fontos terápiás célpontként, amit különösen az tesz hangsúlyossá, hogy a stroma normális szöveti sejtjei a tumorsejtekkel szemben nagyfokú genetikai stabilitást és kisebb fenotípusos varianciát mutatnak, így könnyen válhatnak a komplex, mérhetetlenül diverz rákos megbetegedések Achilles-sarkává.

A tumor-mikrokörnyezet terápiás célzása legelőször az anti-VEGF-A ellenanyagokkal és egyéb, angiogenezist gátló gyógyszerekkel végzett anti-angiogenikus terápiákban valósult meg. Az első ellentmondásos eredmé- 


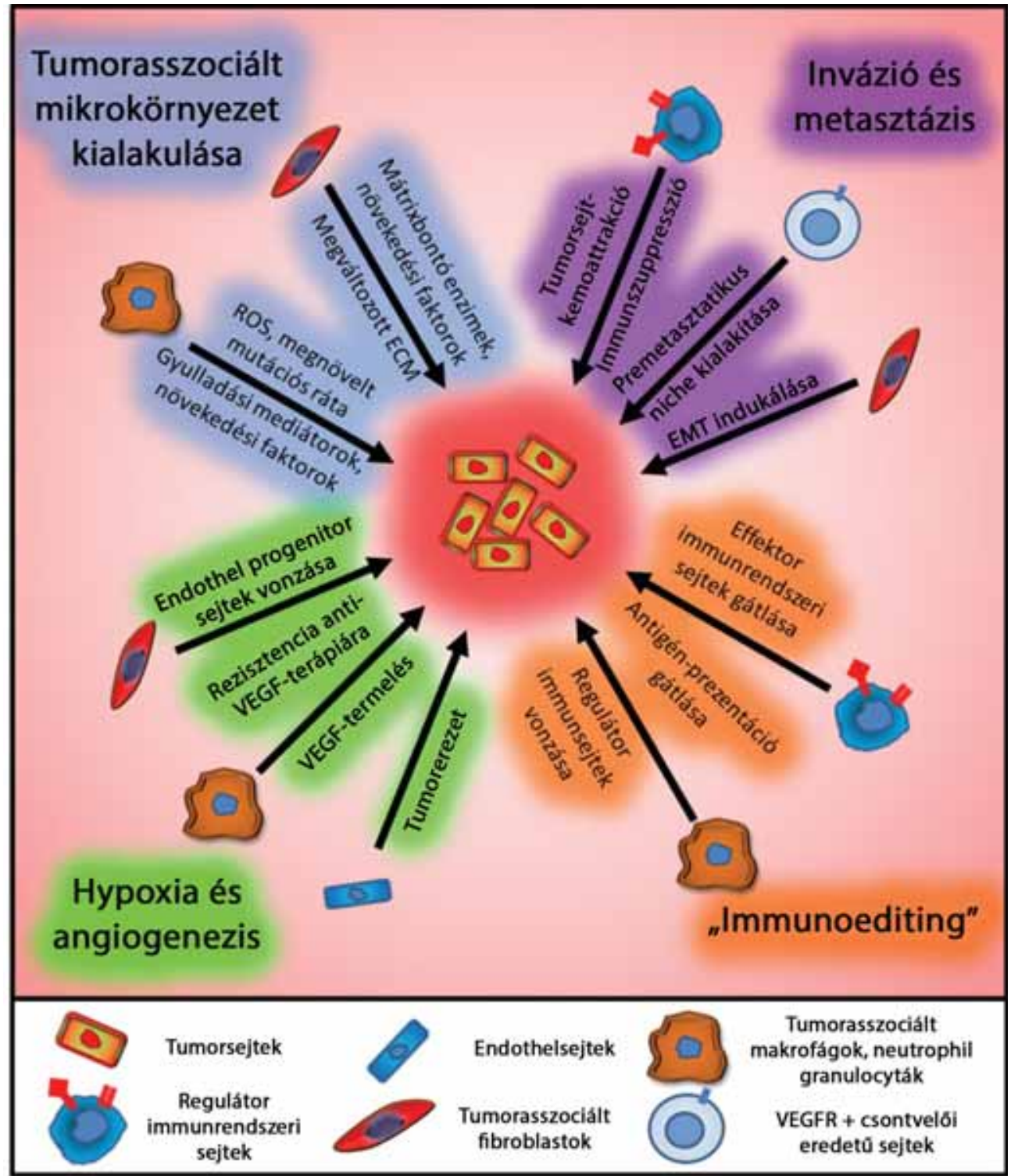

1. ábra

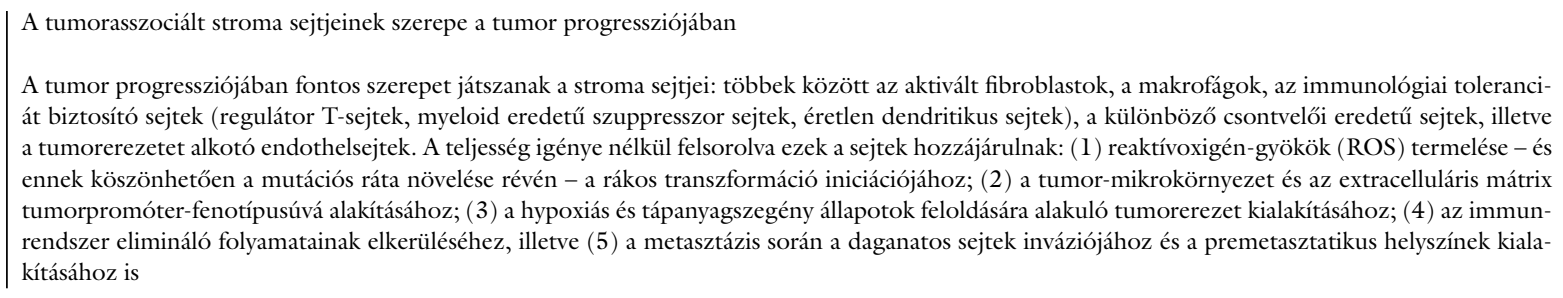

nyek többek között arra hívták fel a figyelmet, hogy a mikrokörnyezet tumorsegítő pillérei közül kizárólag csak az egyik megcélzása könnyen vezethet rezisztenciához vagy akár a tumor agresszívebbé válásához. Ezzel szemben ma már többen próbálkoznak a mikrokörnyezet több komponensét is célzó citotoxikus kezeléssel kombinált terápiával.

Mivel a rákos sejtek progressziójához szükséges különböző mechanizmusokat nagymértékben segíti a stromasejtek múködésének megváltozása, ennek kombinált gátlása felerősítheti a citotoxikus kemoterápia és az immunrendszer által közvetített antitumorhatást. Ugyanakkor komolyabb mellékhatásokkal sem kell szá- molni, mivel az egészséges szöveteket nem érintik ezek a kezelések. Fontos terápiás lehetőség az immunrendszer tumorellenes aktivitásának erősítése, amelynek során az effektor sejtek aktiválásával vagy akár passzív immunizálással érhetô el a rákos sejtek pusztulása. Fontos megjegyezni, hogy a terápia során nemcsak lokálisan, hanem szisztémás mértékben kell az antitumorhatásokat erősíteni, mivel mikrometasztázisok a daganat fejlódésének korai szakaszában is kialakulhatnak. Ha ezekre nem hat a terápia, a rák kiújulásának esélye megnő a kezelés után.

A fenti megállapítások, illetve több új, tumor-mikrokörnyezetet célzó kezelésre vonatkozó konkrét ered- 
mény alapján az alábbi következtetéseket lehet levonni a jövőre nézve:

- Az angiogenezis gátlását célzó terápiák helyett a tumorerezet „normalizálását”, stabil, érett erezetté alakító kezelését érdemes preferálni. Ezzel - a fokozottabb perfúzió révén - el lehetne érni a gyógyszerek hatékonyabb disztribúcióját és tumorsejtekhez érését, ezenkivül a több szempontból is tumorpromóternek számító hypoxiás állapotokat is mérsékelni lehetne [48]. A tumorerezet másik ígéretes manipulációja lehet, ha átjárhatóbbá teszik az effektor immunrendszeri sejtek számára, lehetővé téve azok fokozott antitumor-aktivitását [49].

- A különböző, tumorasszociált stromát alkotó sejtek populációinak, valamint tumorsegítő tevékenységének azonosítása kulcsfontosságú a kezelések hatékonyabbá tételének érdekében. Egyik fontos célpontként szerepelnek a tumorokban általánosan megtalálható tumorasszociált fibroblastok. Ígéretes lehetőség a jövô klinikai gyakorlata számára mind számuk csökkentése, mind a rajtuk megtalálható specifikus antigének (például fibroblast activation protein $\alpha-\mathrm{FAP}-\alpha$ ) tumorhoz kötött lokalizációjának kihasználása a terápiás anyagok disztribúciójában [50].

- Szintén ígéretes kezelési mód a stromában található makrofágok átprogramozása a tumorsegítő M2 fenotípusból az antitumor-aktivitású Ml fenotípusba [13]. Így egyrészt direkt és (T-sejtek aktiválása révén) indirekt módon is tumorsejtpusztító hatást fejtenek ki; másrészt a tumor immunszuppresszív és proliferatív citokinmiliőjét is segítenek ellentétes hatásúra változtatni. Másik lehetőség a tumorból való eltávolításuk, kimerítésük - bár ennek a módszernek nagyobb jelentősége van az MDSC-k, Treg-sejtek és egyéb immunszuppresszív hatású sejtek esetében.

- Amennyiben ez utóbbiak tevékenységét gátoljuk, az effektor immunsejtek (Tc-sejtek, NK-sejtek, citolitikus T-sejtek) hatékonyan tudják eliminálni a rákos sejteket, ami akár a daganat teljes visszafejlődéséhez is vezethet. Ezt a gátlást elő lehet segíteni megfelelő citokinkörnyezet megteremtésével, amit intravénás vagy a még hatásosabb intratumorális injektálással lehet megvalósítani. Az antigén-prezentáció és Tc-sejt-aktiválás elősegítése nekrotikus tumorsejtek hozzáadásával - a megfelelő citokinkörnyezetben - különösen hatékonynyá teheti az immunrendszer antitumor-aktivitását [51].

Bár a klinikai gyakorlat irányában elindított valamenynyi, a tumor mikrokörnyezetét és a stromát célzó terápiás szer és módszer felsorolása meghaladja e tanulmány kereteit, összességében megállapítható, hogy a jövőben a rák kezelésének módszereiben jelentôs változásokra lehet számítani. Ez különösen annak fényében fontos, hogy a rákos megbetegedések kezelésére általában leginkább esélyesnek tartott személyre szabott (immun)terápiával szemben, a mikrokörnyezetet célzó sikeres kombinált kezelés jóval kevésbé költséges, általánosíthatóbb és így mindenki számára elérhető lehet. Ezek az új módszerek tehát lehetővé tehetik, hogy az eddig reménytelennek tartott, legtöbbször halálos kimenetelü daganatos betegségek gyógyítása is megvalósulhasson a klinikai gyakorlatban.

Anyagi támogatás: A közlemény megírása és az ahhoz kapcsolódó kutatómunka anyagi támogatásban nem részesült.

Szerzôi munkamegosztás: B. M.: Szakirodalmi kutatómunka, a kézirat szövegezése. L. M.: A kézirat szövegezése. Sz. Zs.: Szakmai témavezetés, a kézirat szövegezése. A cikk végleges változatát mindhárom szerző elolvasta és jóváhagyta.

Érdekeltségek: A szerzőknek nincsenek érdekeltségeik.

\section{Irodalom}

[1] Coussens, L. M., Werb, Z.: Inflammation and cancer. Nature, 2002, 420(6917), 860-867.

[2] Anderberg, C., Li, H., Fredriksson, L., et al.: Paracrine signalling by platelet derived growth factor-CC promotes tumor growth by recruitment of cancer-associated fibroblasts. Cancer Res., 2009, 69(1), 369-378.

[3] Kojima, Y., Acar, A., Eaton, E. N., et al:: Autocrine TGF-beta and stromal cell-derived factor-1 (SDF-1) signaling drives the evolution of tumor-promoting mammary stromal myofibroblasts. Proc. Natl. Acad. Sci. U.S.A., 2010, 107(46), 2000920014.

[4] Lu, P., Weaver, V. M., Werb, Z.: The extracellular matrix: a dynamic niche in cancer progression. J. Cell Biol., 2012, 196(4), 395-406.

[5] Netti, P. A., Berk, D. A., Swartz, M. A., et al.: Role of extracellular matrix assembly in interstitial transport in solid tumors. Cancer Res., 2000, 60(9), 2497-2503.

[6] Tan, Z. J., Hu, X. G., Cao, G. S., et al.: Analysis of gene expression profile of pancreatic carcinoma using cDNA microarray. World J. Gastroenterol., 2003, 9(4), 818-823.

[7] Koenig, A., Mueller, C., Hasel, C., et al.: Collagen type I induces disruption of E-cadherin-mediated cell-cell contacts and promotes proliferation of pancreatic carcinoma cells. Cancer Res., 2006, 66(9), 4662-4671.

[8] Yu, Q., Stamenkovic, I.: Cell surface-localized matrix metalloproteinase-9 proteolytically activates TGF-beta and promotes tumor invasion and angiogenesis. Genes Dev., 2000, 14(2), 163-176.

[9] Maretzky, T., Reiss, K., Ludwig, A., et al.: ADAM10 mediates Ecadherin shedding and regulates epithelial cell-cell adhesion, migration, and beta-catenin translocation. Proc. Natl. Acad. Sci. U.S.A., 2005, 102(26), 9182-9187.

[10] Shields, J. D., Kourtis, I. C., Tomei, A. A., et al.: Induction of lymphoidlike stroma and immune escape by tumors that express the chemokine CCL21. Science, 2010, 328(5979), 749-752.

[11] Bronte, V., Apolloni, E., Cabrelle, A., et al.: Identification of a $\mathrm{CDllb}(+) / \mathrm{Gr}-1(+) / \mathrm{CD} 3 \mathrm{l}(+)$ myeloid progenitor capable of activating or suppressing CD8(+) T cells. Blood, 2000, 96(12), 3838-3846.

[12] Li, H., Han, Y., Guo, Q., et al.: Cancer-expanded myeloid-derived suppressor cells induce anergy of NK cells through membrane-bound TGF-beta 1. J. Immunol., 2009, 182(1), 240-249.

[13] Mantovani, A., Locati, M.: Tumor-associated macrophages as a paradigm of macrophage plasticity, diversity, and polarization: 
lessons and open questions. Arterioscler. Thromb. Vasc. Biol., 2013, 33(7), 1478-1483.

[14] Crawford, Y., Kasman, I., Yu, L., et al.: PDGF-C mediates the angiogenic and tumorigenic properties of fibroblasts associated with tumors refractory to anti-VEGF treatment. Cancer Cell, 2009, 15(1), 21-34.

[15] Orimo, A., Gupta, P. B., Sgroi, D. C., et al.: Stromal fibroblasts present in invasive human breast carcinomas promote tumor growth and angiogenesis through elevated SDF-1/CXCL12 secretion. Cell, 2005, 121(3), 335-348.

[16] Stockmann, C., Doedens, A., Weidemann, A., et al.: Deletion of vascular endothelial growth factor in myeloid cells accelerates tumorigenesis. Nature, 2008, 456(7223), 814-818.

[17] Rolny, C., Mazzone, M., Tugues, S., et al.: HRG inhibits tumor growth and metastasis by inducing macrophage polarization and vessel normalization through downregulation of PIGF. Cancer Cell, 2011, 19(1), 31-44.

[18] Mittal, D., Gubin, M. M., Schreiber, R. D., et al.: New insights into cancer immunoediting and its three component phases elimination, equilibrium and escape. Curr. Opin. Immunol., 2014, 27, 16-25

[19] Bellamy, W. T., Richter, L., Sirjani, D., et al.: Vascular endothelial cell growth factor is an autocrine promoter of abnormal localized immature myeloid precursors and leukemia progenitor formation in myelodysplastic syndromes. Blood, 2001, 97(5), 14271434.

[20] Oyama, T., Ran, S., Ishida, T., et al.: Vascular endothelial growth factor affects dendritic cell maturation through the inhibition of nuclear factor-kappa B activation in hemopoietic progenitor cells. J. Imunol., 1998, 160(3), 1224-1232.

[21] Yang, L., Pang, Y., Moses, H. L.: TGF- $\beta$ and immune cells: an important regulatory axis in the tumor microenvironment and progression. Trends Immunol., 2010, 31(6), 220-227.

[22] Bellinghausen, I., Brand, U., Steinbrink, K., et al.: Inhibition of human allergic T-cell responses by IL-10-treated dendritic cells: Differences from hydrocortisone-treated dendritic cells. J. Allergy Clin. Immunol., 2001, 108(2), 242-249.

[23] Corinti, S., Albanesi, C., la Sala, A., et al.: Regulatory activity of autocrine IL-10 on dendritic cell functions. J. Imunol., 2001, $166(7), 4312-4318$.

[24] Munder, M.: Arginase: an emerging key player in the mammalian immune system. Br. J. Pharmacol., 2009, 158(3), 638-651.

[25] Prendergast, G. C.: Immune escape as a fundamental trait of cancer: focus on IDO. Oncogene, 2008, 27(28), 3889-3900.

[26] Uyttenhove, C., Pilotte, L., Théate, I., et al.: Evidence for a tumoral immune resistance mechanism based on tryptophan degradation by indoleamine 2,3-dioxygenase. Nat. Med., 2003, 9(10), 1269-1274.

[27] Hwu, P., Du, M. X., Lapointe, R., et al.: Indoleamine 2,3-dioxygenase production by human dendritic cells results in the inhibition of T cell proliferation. J. Immunol., 2000, 164(7), 35963599.

[28] Munder, M., Eichmann, K., Modolell, M.: Alternative metabolic states in murine macrophages reflected by the nitric oxide synthase/arginase balance: competitive regulation by $\mathrm{CD} 4+\mathrm{T}$ cells correlates with Thl/Th2 phenotype. J. Immunol., 1998, 160(11), 5347-5354.

[29] Rodriguez, P. C., Quiceno, D. G., Zabaleta, J., et al.: Arginase I production in the tumor microenvironment by mature myeloid cells inhibits T-cell receptor expression and antigen-specific Tcell responses. Cancer Res., 2004, 64(16), 5839-5849.

[30] Rodriguez, P. C., Quiceno, D. G., Ochoa, A. C.: L-arginine availability regulates T-lymphocyte cell-cycle progression. Blood, 2007, 109(4), 1568-1573.

[31] Vignali, D. A., Collison, L. W., Workman, C. J.: How regulatory T cells work. Nat. Rev. Immunol., 2008, 8(7), 523-532.
[32] Cheng, C., Qu, Q. X., Shen, Ү., et al.: Overexpression of B7-H4 in tumor infiltrated dendritic cells. J. Immunoassay Immunochem., 2011, 32(4), 353-364.

[33] Ghiringhelli, F., Puig, P. E., Roux, S., et al.: Tumor cells convert immature myeloid dendritic cells into TGF-beta-secreting cells inducing $\mathrm{CD} 4+\mathrm{CD} 25+$ regulatory $\mathrm{T}$ cell proliferation. J. Exp. Med., 2005, 202(7), 919-929.

[34] Bronte, V., Kasic, T., Gri, G., et al.: Boosting antitumor responses of $\mathrm{T}$ lymphocytes infiltrating human prostate cancers. J. Exp. Med., 2005, 201(8), 1257-1268.

[35] Gabrilovich, D. I., Nagaraj, S.: Myeloid-derived suppressor cells as regulators of the immune system. Nat. Rev. Immunol., 2009, $9(3), 162-174$

[36] Hiratsuka, S., Watanabe, A., Aburatani, H., et al.: Tumor-mediated upregulation of chemoattractants and recruitment of myeloid cells predetermines lung metastasis. Nat. Cell Biol., 2006, 8(12), 1369-1375

[37] Kaplan, R. N., Riba, R. D., Zacharoulis, S., et al.: VEGFRI-positive haematopoietic bone marrow progenitors initiate the premetastatic niche. Nature, 2005, 438(7069), 820-827.

[38] Erler, J. T., Bennewith, K. L., Cox, T. R., et al.: Hypoxia-induced lysyl oxidase is a critical mediator of bone marrow cell recruitment to form the premetastatic niche. Cancer Cell, 2009, 15(1), $35-44$.

[39] Yan, H. H., Pickup, M., Pang, Y., et al.: Gr-1+CDllb+ myeloid cells tip the balance of immune protection to tumor promotion in the premetastatic lung. Cancer Res., 2010, 70(15), 61396149.

[40] Hanahan, D., Coussens, L. M.: Accessories to the crime: functions of cells recruited to the tumor microenvironment. Cancer Cell, 2012, 21(3), 309-322.

[41] Hanahan, D., Weinberg, R. A.: Hallmarks of cancer: the next generation. Cell, 2011, 144(5), 646-674.

[42] Radisky, D. C., Levy, D. D., Littlepage, L. E., et al.: Raclb and reactive oxygen species mediate MMP-3-induced EMT and genomic instability. Nature, 2005, 436(7047), 123-127.

[43] $L v, Z$. D., Kong, B., Li, J. G., et al.: Transforming growth factor- $\beta 1$ enhances the invasiveness of breast cancer cells by inducing a Smad2-dependent epithelial-to-mesenchymal transition. Oncol. Rep., 2013, 29(1), 219-225

[44] Wyckoff, J., Wang, W., Lin, E. Ү., et al.: A paracrine loop between tumor cells and macrophages is tequired for tumor cell migration in mammary tumors. Cancer Res., 2004, 64(19), 7022-7029.

[45] Gay, L. J., Felding-Habermann, B.: Contribution of platelets to tumor metastasis. Nat. Rev. Cancer, 2011, 11(2), 123-134.

[46] Kim, S., Takahashi, H., Lin, W. W., et al.: Carcinoma-produced factors activate myeloid cells through TLR2 to stimulate metastasis. Nature, 2009, 457(7225), 102-106.

[47] Hiratsuka, S., Goel, S., Kamoun, W. S., et al.: Endothelial focal adhesion kinase mediates cancer cell homing to discrete regions of the lungs via E-selectin up-regulation. Proc. Natl. Acad. Sci. U.S.A., 2011, 108(9), 3725-3730.

[48] Jain, R. K.: Normalization of tumor vasculature: an emerging concept in antiangiogenic therapy. Science, 2005, 307(5706), $58-62$.

[49] Hamzah, J., Nelson, D., Moldenhauer, G., et al.: Vascular targeting of anti-CD40 antibodies and IL-2 into autochthonous tumors enhances immunotherapy in mice. J. Clin. Invest., 2008, 118(5), 1691-1699.

[50] Kalluri, R., Zeisberg, M.: Fibroblasts in cancer. Nat. Rev. Cancer, 2006, 6(5), 392-401.

[51] Nelson, D., Fisher, S., Robinson, B.: The "Trojan Horse" approach to tumor immunotherapy: targeting the tumor microenvironment. J. Immunol. Res., 2014, 2014, 789069.

(Baranyi Marcell, Gyúró, Thököly u. 26., 2464 e-mail: baranyi2marci@gmail.com) 